\title{
Identifikasi ikan gabus, Channa spp. (Scopoli 1777) stok liar dan generasi I hasil domestikasi berdasarkan gen Cytochrome C Oxidase Subunit I (COI)
}

\author{
[Identification of wild stock and the first generation (F1) of domesticated snakehead fish, Channa \\ spp. (Scopoli 1777) using partial Cytochrome C Oxidase Subunit I (COI) gene]
Irmawati $^{1 \bowtie}$, Joeharnani Tresnati ${ }^{1}$, Nadiarti $^{1}$, Liestiaty Fachruddin ${ }^{1}$, Nur Rahmawaty Arma $^{2}$, Andi Haerul \\ ${ }^{1}$ Jurusan Perikanan, Fakultas Ilmu Kelautan dan Perikanan, Universitas Hasanuddin, \\ Jln. Perintis Kemerdekaan Km 10, Makassar, 90245 \\ ${ }^{2}$ Program Studi Budidaya Perairan, Politeknik Pertanian Negeri Pangkep,
}

Jln. Poros Makassar-Parepare Km 83 Mandalle, Kabupaten Pangkajene dan Kepulauan, 90655

Diterima: 22 Oktober 2016; Disetujui: 11 April 2017

\begin{abstract}
Abstrak
Populasi ikan gabus (famili Channidae) tersebar luas di wilayah perairan tawar Indonesia. Ikan gabus merupakan ikan asli di Sumatera, Jawa, dan Kalimantan) tetapi merupakan ikan introduksi di Sulawesi dan Papua. Identifikasi berdasarkan gen cytochrome c oxidase subunit I (COI) telah dilakukan terhadap ikan gabus dari perairan di Tasikmalaya, Ambarawa, Bali, Aceh, Pontianak dan Banjarmasin, tetapi ikan gabus dari perairan Sulawesi Selatan belum dilakukan. Tujuan penelitian adalah untuk mengidentifikasi species ikan gabus dari Danau Towuti Sorowako dan ikan gabus generasi I (F1) hasil domestikasi dari induk yang berasal dari perairan tawar Kabupaten Bantaeng Sulawesi Selatan menggunakan gen COI untuk DNA barcoding, dan untuk menganalisis filogeni ikan gabus tersebut. Sekuen gen COI ikan gabus tersebut disejajarkan dengan sekuen nukleotida ikan gabus yang terdeposit di GenBank. Pohon filogenetik dikonstruksi dengan menggunakan program MEGA 7.0.20. Hasil penelitian menunjukkan bahwa nukleotida gen COI sampel ikan gabus dari Danau Towuti Sorowako memiliki kemiripan 99\% dengan Channa striata nomor aksesi KU692418 dan KU692421 dan 98\% dengan Channa striata nomor aksesi KU852443 sehingga dapat disimpulkan bahwa di Danau Towuti terdapat ikan gabus jenis Channa striata. Tingkat kemiripan sekuen nukleotida ikan gabus F1dari perairan Kabupaten Bantaeng adalah 65\% dengan ikan gabus Channa pleurophthalma (KJ937390) asal perairan Banjarmasin dan ikan gabus Channa gachua (KX389277). Berdasarkan hasil tersebut maka diduga bahwa ikan gabus dari Danau Towuti Sorowako berkerabat jauh dengan ikan gabus dari perairan Bantaeng, dan diperlukan analisis yang lebih lanjut untuk menentukan jenis populasi ikan gabus F1 asal perairan tawar Kabupaten Bantaeng tersebut.
\end{abstract}

Kata penting: filogenetik, gabus, cytochrome c oxidase subunit I (COI),

\begin{abstract}
The snakehead fish (Channidae) is widely distributed in inland water of Indonesia. This fish is native species in Sumatera, Java and Kalimantan, but non-native species in Sulawesi and Papua. Study on molecular identification and phylogeny of this fish using cytochrome c oxidase subunit I (COI) gene has only been conducted on snakehead fish origin from Tasikmalaya, Ambarawa, Bali, Aceh, Pontianak, and Banjarmasin waters, but none is available in South Sulawesi waters. The objectives of this research are to identify species of snakehead fish from Towuti Lake Sorowako and the first generation (F1) of domesticated snakehead fish from Bantaeng waters of South Sulawesi using COI gene for DNA barcoding, and to analyze the phylogenetic resolution of the fish. Partial sequences of the COI gene of the snakehead fish were aligned with sequences of snakehead fish deposited in GenBank. The phylogenetic tree was constructed using MEGA 7.0.20 program. The result indicated that COI gene nucleotides of snakehead fish from Towuti Lake Sorowako showed 99\% homology with Channa striata acc no. KU692418 and KU692421, and showed 98\% homology with those of acc no. KU852443. Therefore it can be conclude that Channa striata exist in Towuti Lake Sorowako. Nucleotide sequences of the first generation (F1) of domesticated snakehead fish from Bantaeng waters showed 65\% homology with Channa pleurophthalma (acc no. KJ937390) origins from Banjarmasin waters and Channa gachua (acc no. KX389277). Based on this result, it assumed that snakehead fish from Towuti Lake Sorowako are distantly in gene to those from Bantaeng waters, and further analyses are required to identify the population of snakehead fish from Bantaeng waters.
\end{abstract}

Keywords: Channa striata, phylogenetic, cytochrome c oxidase subunit I (COI), snakehead fish

$\overline{\triangle \text { Penulis korespondensi }}$
Alamat surel: trif.ahwa@gmail.com 


\section{Pendahuluan}

Ikan gabus, snakehead fish, yang dikenal sebagai spesies invasif, merupakan ikan dari famili Channidae. Famili Channidae terdiri dari dua genera, yaitu Channa dan Parachanna. Genus Channa terdiri dari 34 spesies dan merupakan ikan asli di wilayah Asia sedangkan genus Parachanna terdiri atas tiga spesies dan merupakan ikan asli di wilayah Afrika (Froese \& Pauly 2016). Ikan gabus tersebar hampir di seluruh wilayah perairan umum daratan Indonesia. Ikan gabus di Indonesia merupakan ikan asli di wilayah perairan umum daratan di paparan Sunda (Sumatera, Jawa, dan Kalimantan) sedangkan ikan gabus yang terdapat di wilayah perairan umum daratan Wallacea (Sulawesi, Sunda Kecil, Maluku) dan Paparan Sahul (Papua) merupakan ikan introduksi.

Ikan gabus telah banyak dieksploitasi karena diketahui memiliki potensi farmaseutika (Mat Jais et al. 1997; Michelle et al. 2004). Ikan gabus juga kaya akan albumin, asam lemak, asam amino, dan mineral (Mustafa et al. 2012). Kandungan gelatin dan kolagen pada bagian kulit dan tulang menyebabkan ikan gabus di Indonesia banyak dieksploitasi untuk kebutuhan industri.

Keanekaragaman jenis ikan gabus cukup tinggi di Indonesia. Muchlisin et al. (2013) mengidentifikasi dua jenis ikan gabus di Danau Laut Tawar Aceh, yaitu ikan gabus jenis Channa gachua dan Channa striata. Lebih jauh Serrao et al. (2014) melaporkan bahwa ikan gabus yang tersebar di perairan tawar Indonesia adalah ikan gabus dari jenis C. bankanensis, C. cyanospilos, C. gachua, C. marulioides, C. melanoptera, C. melasoma, C. micropeltes, C. lucius, C. striata dan Channa pleurophthalma. Dahruddin et al. (2017) melaporkan bahwa ikan gabus Channa striata teridentifikasi di Danau Rawa Pening Jawa Tengah, Cigede Tasikmalaya, dan Tukad
Unda Bali serta ikan gabus jenis Channa pleurophthalma terdapat di Banjarmasin Kalimantan Selatan. Genus Channa yang berbeda jenis tersebut memiliki toleransi ekologi yang berbeda dan kemampuan menginvasi dari setiap spesies juga berbeda (Herborg et al. 2007). Meskipun ikan gabus bukan merupakan ikan asli di Sulawesi Selatan, akan tetapi ikan tersebut ditemukan hampir di seluruh perairan umum daratan Sulawesi Selatan. Ikan gabus ditemukan di Danau Tempe, Danau Sidenreng, Danau Towuti, Danau Matano, dan sungai-sungai serta kanal-kanal di area persawahan. Status taksonomi ikan gabus pada level spesies dari genus Channa di Sulawesi Selatan belum jelas sehingga menarik untuk dikaji.

Identifikasi dan karakterisasi ikan gabus merupakan hal yang sangat penting. Selain terkait dengan kemampuan adaptasi dan invasi yang berbeda (bergantung kepada spesies/jenis), juga terkait dengan budi daya dan pengelolaan serta konservasi ikan gabus di habitat aslinya. Saat ini, informasi tentang identifikasi, karakterisasi, dan distribusi ikan gabus di Indonesia masih sangat terbatas, dan khusus di wilayah perairan umum daratan Sulawesi Selatan belum tersedia.

DNA barcoding berdasarkan parsial sekuen gen COI adalah salah satu metode yang banyak digunakan untuk mengidentifikasi spesies ikan (Hebert et al. 2003a; Lakra et al. 2009). DNA barcoding menggunakan sekitar 650 pasang basa dari segmen gen cytochrome c oxidase subunit I (COI) mitokondria sebagai marka/penanda (Hebert et al. 2003b). Gen COI adalah satu dari dua gen yang mengkode protein yang ditemukan di semua eukariot. COI memiliki laju mutasi asam amino yang sangat rendah (Lynch \& Jerrell 1993) dengan sekuen DNA yang terkonservasi tinggi di dalam spesies yang sama (Lambert et al. 2005). Berdasarkan karakter tersebut, gen COI cukup efisien dan akurat digunakan dalam meng- 
identifikasi spesies eukariot (Ma et al. 2012, Hebert et al. 2003a)

Berdasarkan latar belakang tersebut penelitian ini dirancang dengan tujuan untuk mengidentifikasi sampel ikan gabus yang berasal dari Danau Towuti dan benih ikan gabus generasi I (F1) dari induk alam perairan tawar di Desa Rappoa Kabupaten Bantaeng menggunakan metode DNA barcoding. Hasil penelitian diharapkan bermanfaat bagi studi ikan gabus selanjutnya terutama dalam hal pengelolaan sumber daya ikan gabus dan pengembangan budi daya ikan gabus.

\section{Bahan dan metode}

Sampel ikan gabus

Sampel ikan gabus masing-masing sebanyak dua ekor merupakan ikan hasil tangkapan dari Danau Towuti dan generasi I (F1) hasil domesti- kasi dari induk yang berasal dari perairan tawar di Desa Rappoa Kabupaten Bantaeng (Gambar 1). Sampel ikan gabus dari Danau Towuti diambil pada bulan Juni 2016 dengan menggunakan alat tangkap pancing. Benih ikan gabus F1 berasal dari sepasang induk yang memijah pada bulan Mei 2016 di Balai Benih Ikan (BBI) Rappoa Kabupaten Bantaeng. Sampel insang dan otot dari dua ekor ikan gabus di masing-masing stasiun diawetkan dengan menggunakan Ethanol absolut (Gambar 2).

\section{Ekstraksi DNA}

Ekstraksi DNA dilakukan terhadap sampel ikan asal organ sirip pektoral yang dipreservasi dalam ethanol 70\%. Ekstraksi dilakukan menggunakan DNeasy mini KIT (Qiagen) dengan prosedur mengacu pada manual.

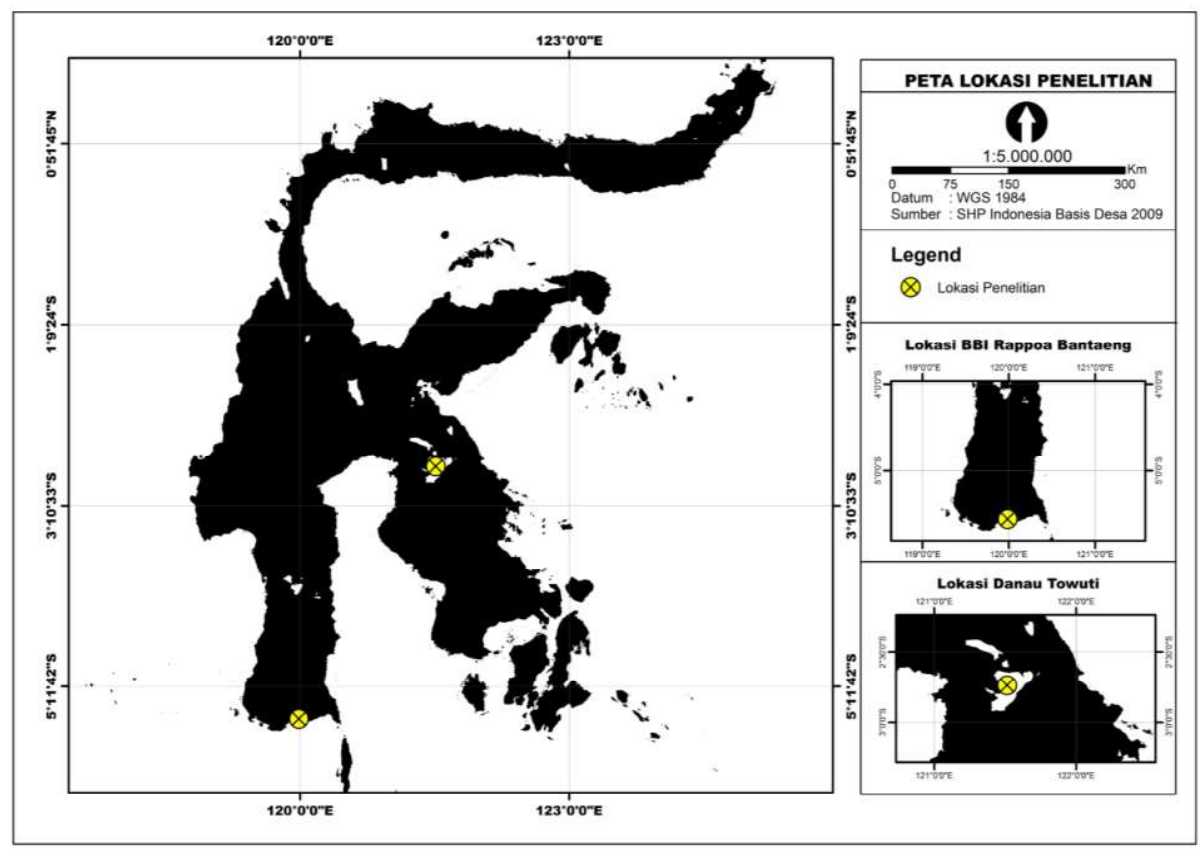

Gambar 1. Lokasi pengambilan sampel. Sampel ikan gabus pada penelitian ini merupakan sampel hasil tangkapan di Danau Towuti dan benih ikan gabus hasil domestikasi dari induk yang berasal dari perairan tawar Kabupaten Bantaeng 


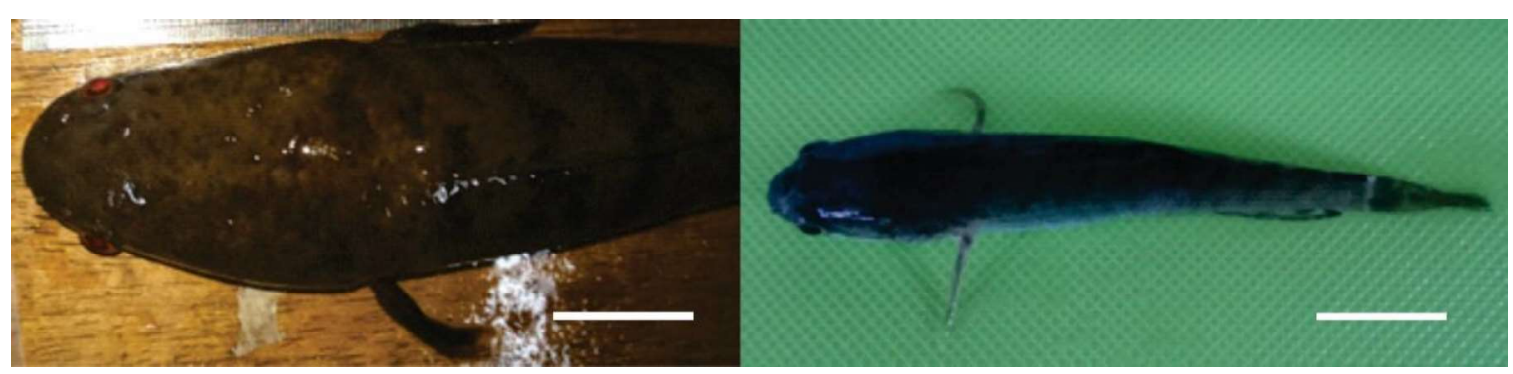

(A)

(B)

Gambar 2. Sampel ikan gabus yang digunakan dalam penelitian. Ikan gabus yang tertangkap di Danau Towuti (A). Ikan gabus generasi I (F1) hasil hibridisasi induk dari perairan tawar Kabupaten Bantaeng (B). Skala bar: $1 \mathrm{~cm}$

\section{Amplifikasi}

Gen COI ikan gabus diamplifikasi menggunakan pasangan primer universal Fish F1: 5'TCA ACC AAC CAC AAA GAC ATT GGC AC- 3' dan Fish R1: 5'- TAG ACT TCT GGG TGG CCA AAG AAT CA -3'. Target segmen DNA dari gen COI dengan menggunakan pasangan primer tersebut adalah sekitar 650 pasang basa (bp). Reaksi PCR untuk $25 \mu \mathrm{L}$ terdiri dari 1 $\mu \mathrm{L}$ masing-masing primer, 12,5 $\mu \mathrm{L}$ KAPA hot start ready mix (berisi: DNA polymerase, $10 \mathrm{mM}$ dNTPs, $25 \mathrm{mM} \mathrm{MgCl} 2$, dan $2 \mathrm{X}$ buffer), 5,5 $\mu \mathrm{L}$ nuclease free water (air bebas enzim nuclease) dan $5 \mu \mathrm{L}$ sampel DNA sebagai cetakan. Proses amplifikasi (penggandaan) DNA di dalam mesin PCR meliputi: predenaturasi (pemisahan untai ganda DNA) pada $94^{\circ} \mathrm{C}$ selama 5 menit; 40 siklus pada $94^{\circ} \mathrm{C}$ selama 30 detik untuk proses denaturasi, $52^{\circ} \mathrm{C}$ selama 30 detik untuk proses annealing (penempelam primer), $72^{\circ} \mathrm{C}$ selama 30 detik untuk proses extension (polimerisasi primer). Proses tersebut diakhiri dengan proses post-extension pada suhu $72^{\circ} \mathrm{C}$ selama 7 menit dan disimpan pada suhu $4^{\circ} \mathrm{C}$.

\section{Visualisasi pita DNA}

Produk PCR selanjutnya dijalankan dalam elektroforesis agarose 1,8\% dalam buffer TAE dengan menggunakan ethidium bromide sebagai pewarna DNA. Elektroforesis dijalankan meng- gunakan tegangan $100 \mathrm{~V}$ selama 45 menit. Produk PCR hasil elektroforesis selanjutnya divisualisasi menggunakan sinar ultraviolet dalam alat GelDoc (BioRad).

\section{Perunutan nukleotida (sequencing)}

Sekuensing dilakukan di $1^{\text {st }}$ BASE Malaysia dengan menggunakan BigDye ${ }^{\circledR}$ Terminator ver. 3.1 cycle sequencing KIT dan mesin otomatis HiSeq-X sequencing. Primer yang digunakan untuk proses sekuensing adalah sama dengan primer yang digunakan untuk proses amplifikasi PCR.

\section{Analisis data}

Sekuen parsial gen COI mitokondria hasil sekuensing dianalisis menggunakan program BioEdit, ClustalW, MEGA, Melecular Evolutionary Genetics Analysis, ver. 7.0.20 (Tamura et al. 2013) dan program BLASTn, Nucleotide The Basic Local Alignment Search Tool dari NCBI. Program MEGA ver. 7.0.20 yang dapat link ke NCBI (National Center of Biotechnology Information), digunakan untuk identifikasi dan mendapatkan gambaran tentang evolusi gen COI ikan gabus stok alami/liar dari Danau Towuti dan ikan gabus hasil domestikasi dari Kabupaten Bantaeng. Identifikasi ikan gabus dilakukan dengan menyejajarkan (alignment) sekuen nukleotida sampel ikan gabus hasil sekuensing dengan se- 
kuen nukleotida gen COI vertebrata lainnya yang terdeposit di Bank Gen. Hasil penyejajaran kemudian dianalisis secara deskriptif.

\section{Hasil}

Amplifikasi genom ikan gabus menghasilkan pita DNA gen COI berukuran sekitar 700 pasang basa (pb) (Gambar 3). Penyejajaran 655 pasang basa $(\mathrm{pb})$ gen COI mitokondria sampel ikan gabus dari Danau Towuti Sulawesi Selatan dengan beberapa sekuen gen COI ikan gabus yang terdeposit di Bank Gen menunjukkan bahwa spesies ikan gabus dari Danau Towuti adalah Channa striata. Sekuen gen COI sampel ikan gabus yang tertangkap di Danau Towuti meliputi 99\% sekuen gen COI Channa striata nomor aksesi:
KU692418 dari Cigede Tasikmalaya Jawa Barat dan Channa striata nomor aksesi: KU692421 dari Danau Rawa Pening Ambarawa Jawa Tengah (Tabel 1).

Penyejajaran 547 pb gen COI mitokondria sampel ikan gabus generasi pertama (F1) dari induk ikan gabus yang tertangkap di perairan tawar Kabupaten Bantaeng dengan beberapa sekuen gen COI vertebrata lainnya menunjukkan bahwa nukleotida gen COI ikan gabus hasil domestikasi tersebut mengcover 100\% nukleotida COI Channa pleuropthalma(nomor aksesi KJ937390) asal Banjarmasin Kalimantan Selatan dan Channa gachua (nomor aksesi KX389277) dengan derajat homologi masing-masing sebesar 65\% (Tabel 2).

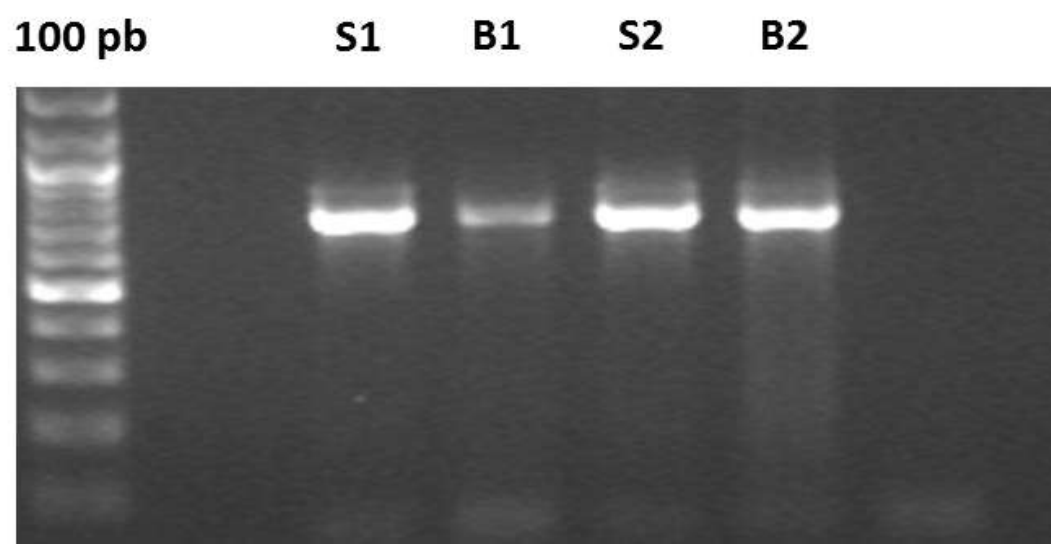

Gambar 3. Pita DNA gen COI hasil amplifikasi genom ikan gabus. S1, S2 = pita DNA gen COI ikan gabus dari Danau Towuti; B1, B2 = pita DNA gen COI benih ikan gabus generasi I (F1) hasil domestikasi dari induk yang berasal dari perairan tawar Kabupaten Bantaeng

Tabel 1. Hasil penyejajaran sekuen gen cytochrome c oxidase subunit I (COI) mitokondria ikan gabus dari Danau Towuti dengan sekuen gen cytochrome c oxidase subunit I (COI) ikan gabus lainnya (\%)

\begin{tabular}{llcc}
\hline \multicolumn{1}{c}{ Nomor aksesi } & \multicolumn{1}{c}{ Takson } & Query cover (\%) & Homologi (\%) \\
\hline KU692418 & $\begin{array}{l}\text { Channa striata (Cigede, Tasikmala- } \\
\text { ya, Jawa Barat) } \\
\text { Channa striata (Danau Rawa Pe- } \\
\text { ning, Jawa Tengah) }\end{array}$ & 99 & 99 \\
KU692421 & $\begin{array}{l}\text { Channa striata (Cigede, Tasikmala- } \\
\text { ya, Jawa Barat) }\end{array}$ & 99 & 99 \\
KU692423 & $\begin{array}{l}\text { Channa striata (Tukad Unda, Bali) } \\
\text { Channa striata (Pontianak, Kali- } \\
\text { KJ937425 }\end{array}$ & 99 & 99 \\
KJ937an Barat) & 99 & 99 \\
Channa striata (Way Batang Hari, & 99 & 99 \\
\hline
\end{tabular}


Tabel 2. Hasil penyejajaran sekuen gen cytochrome c oxidase subunit I (COI) mitokondria ikan gabus generasi I (F1) hasil domestikasi induk yang berasar dari perairan tawar di Kabupaten Bantaeng dengan sekuen gen cytochrome c oxidase subunit I (COI) ikan gabus lainnya (\%)

\begin{tabular}{llcc}
\hline \multicolumn{1}{c}{ Nomor aksesi } & \multicolumn{1}{c}{ Takson } & Query cover (\%) & Homologi (\%) \\
\hline KJ937390 & $\begin{array}{l}\text { Channa pleuropthalma } \\
\text { (Banjarmasin Indonesia) }\end{array}$ & 100 & 65 \\
KX389277 & Channa gachua (India) & 100 & 65 \\
KU495729 & Channa microcephalus (Filipina) & 100 & 63 \\
JX260840 & Channa marulius (India) & 34 & 71 \\
KX389275 & Channa punctate (India) & 31 & 73 \\
\hline
\end{tabular}

Pohon filogenetik menunjukkan bahwa sampel ikan gabus yang tertangkap di Danau Towuti membentuk satu kelompok dengan Channa striata dari Tasikmalaya Jawa Barat (no aksesi KU692418), Channa striata asal Danau Rawa Pening, Jawa Tengah (no aksesi: KU692421), dan Channa striata asal Bali (no aksesi KU692423). Channa striata yang berasal dari Aceh membentuk kelompok lain bersama-sama dengan Channa striata dari Filipina, Vietnam, Thailand, dan Tiongkok. Ikan gabus generasi I
(F1) dari induk yang tertangkap di perairan tawar Kabupaten Bantaeng memiliki hubungan kekerabatan terdekat dengan Channa pleurophthalma (no aksesi KJ937390) asal Banjarmasin Kalimantan Selatan dan Channa gachua (no aksesi KX389277) yang berasal dari India. Ikan gabus yang tertangkap di Danau Towuti berkerabat jauh dengan ikan gabus generasi I (F1) dari induk alam yang tertangkap di perairan tawar Kabupaten Bantaeng (Gambar 4 dan 5).

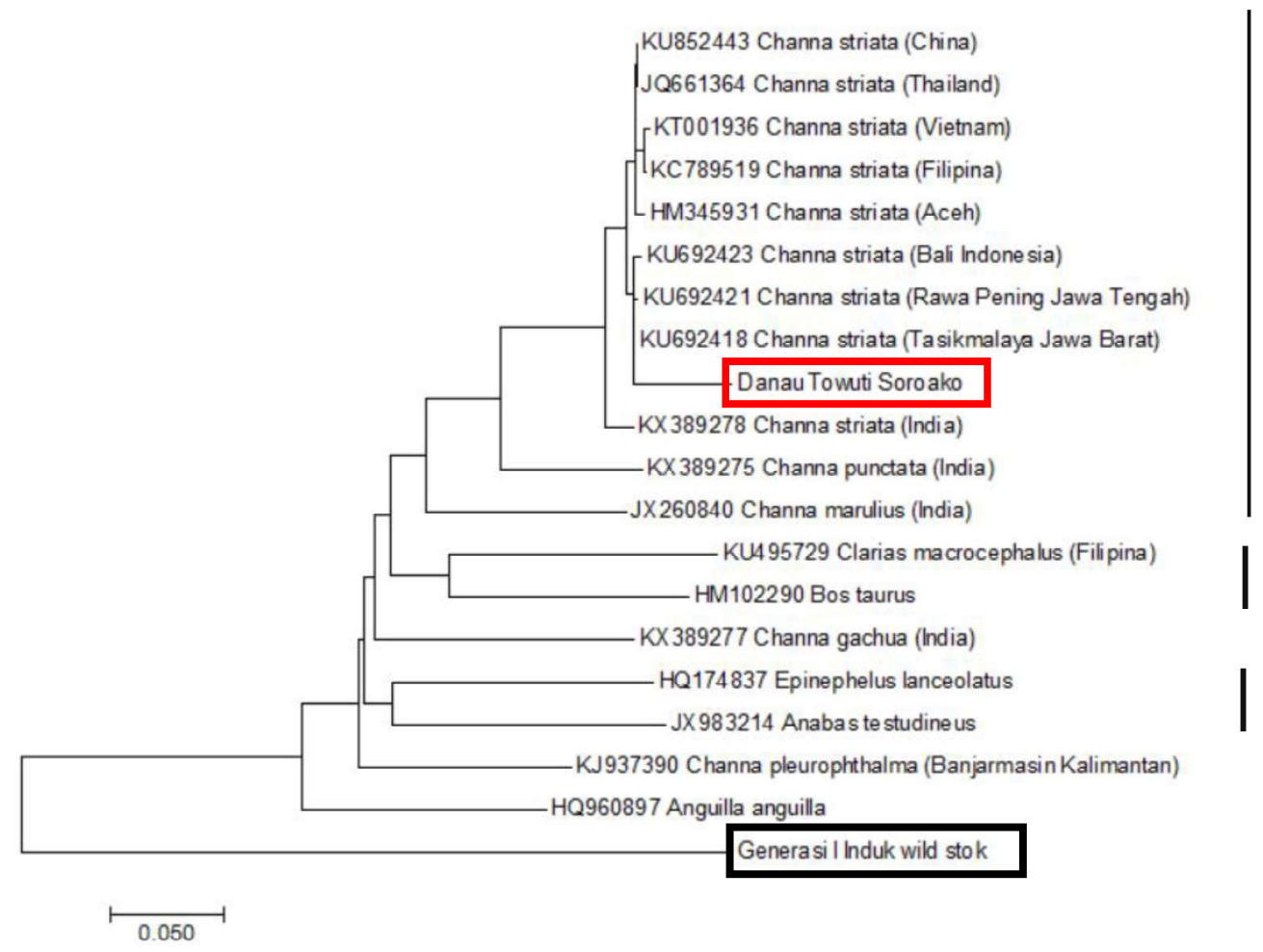

Gambar 4. Filogeni ikan gabus (Channa striata) dari Danau Towuti (Soroako) dan generasi I (F1) hasil domestikasi induk yang berasal dari perairan tawar di Kabupaten Bantaeng dengan beberapa spesies ikan dan vertebrata lainnya berdasarkan sekuen gen cytochrome c oxidase subunit I (COI) 


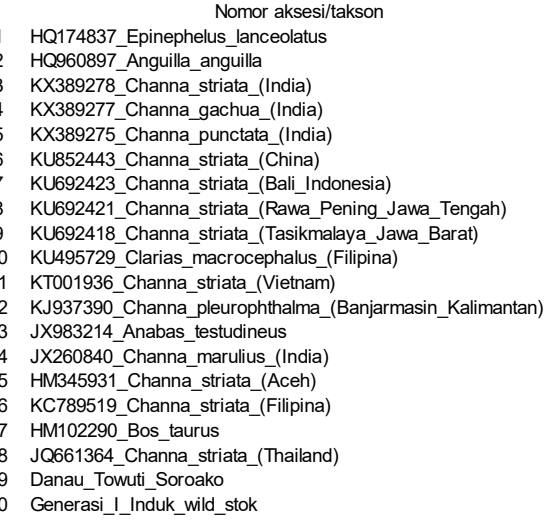

Gambar 5. Jarak genetik sampel ikan gabus (Channa striata) dari Danau Towuti (Soroako) dan generasi I (F1) hasil domestikasi induk yang berasal dari perairan tawar di Kabupaten Bantaeng dengan beberapa spesies ikan dan vertebrata lainnya berdasarkan sekuen gen cytochrome c oxidase subunit I (COI)

\section{Pembahasan}

Identifikasi jenis yang akurat dan hubungan kekerabatan antarjenis sangat dibutuhkan dalam pengelolaan sumber daya hayati perairan dan program pemuliabiakan ikan. Identifikasi berdasarkan DNA barcoding terbukti mampu mengelompokkan sampel-sampel ikan gabus pada penelitian ini ke dalam kelompok taksanya. Analisis filogeni menunjukkan bahwa sampel ikan gabus yang tertangkap di Danau Towuti berada satu kelompok dengan Channa striata asal Tasikmalaya Jawa Barat, Danau Rawa Pening Jawa Tengah, dan Channa striata yang berasal dari Bali. Hebert et al. (2004) menyatakan bahwa DNA barcoding adalah metode yang telah dibakukan untuk mengidentifikasi spesies berdasarkan fragmen gen COI. DNA barcoding diramalkan sebagai solusi untuk mempercepat laju penemuan spesies baru dan membuka perspektif baru dalam konservasi. Oleh karena itu, DNA barcoding merupakan solusi cepat dan tepat dalam mengungkap keanekaragaman hayati sebelum mengarah ke kondisi kepunahan sebagai akibat pemanasan global dan degradasi lingkungan.

Beberapa penelitian yang dilakukan menunjukkan bahwa identifikasi ikan gabus secara mor- fologi memiliki keterbatasan karena ikan gabus memiliki variasi morfologi yang sangat kecil di antara individu. Identifikasi secara morfometrik dan meristik terhadap ikan gabus dari wilayah perairan tawar Kabupaten Wajo dan perairan payau di daerah Batangase serta Sungai Maros di Kabupaten Maros menunjukkan bahwa karakter penciri ikan gabus dari setiap daerah tersebut berbeda-beda atau tidak konsisten (Arma et al. 2014, Irmawati et al. 2015). Hal tersebut sejalan dengan hasil penelitian Song et al. (2013) yang menemukan bahwa keragaman genetik dalam spesies Channa striata lebih rendah dibandingkan dengan spesies-spesies lainnya dan tidak berkorelasi dengan variasi morfologi. Hasil penelitian Zhu et al. (2013) menunjukkan bahwa identifikasi ikan gabus berdasarkan karakter morfologi menunjukkan hasil yang sangat tidak menentu karena keanekaragaman ikan gabus yang tinggi.

Nukleotida gen COI mitokondria ikan gabus dari Danau Towuti memiliki homologi yang tinggi dengan Channa striata dari Tasikmalaya Jawa Barat nomor aksesi KU692418, Danau Rawa Pening Jawa Tengah nomor aksesi KU692421, Bali (KU692423), Lampung (KJ937421), dan Pontianak Kalimantan Barat (KJ937425) yaitu sebesar 
99\%. Tingkat homologi ikan gabus dari Danau Towuti dengan ikan gabus dari Tiongkok (KU852443), Filiphina (KC789519, HQ682668), dan Thailand (KJ937376) adalah sebesar 98\%. Tingkat homologi sekuen nukleotida gen COI ikan gabus dari Danau Towuti sebesar 98 - 99\% dengan Channa striata dari beberapa daerah menunjukkan bahwa ikan gabus tersebut adalah Channa striata. Identifikasi ikan gabus dari Danau Towuti sebagai Channa striata juga dipertegas oleh data tentang jarak genetik dan gap/situs polimorfik/keragaman sekuen gen COI. Jarak genetik antara ikan gabus dari Danau Towuti dengan ikan gabus dari Tasikmalaya, Jawa Tengah, Bali, Aceh, Tiongkok, Thailand, Filiphina, dan Vietnam adalah sebesar 4,3-5,1\% menunjukkan bahwa ikan gabus-ikan gabus tersebut berkerabat sangat dekat. Muchlisin et al. (2013) menyatakan bahwa jarak nukleotida sebesar 7,1\% menunjukkan tingkat kekerabatan yang sangat dekat. Gap atau situs polimorfik yang menggambarkan keragaman nukleotida gen COI ikan gabus dari Danau Towuti dengan Channa striata dari beberapa wilayah yang disebutkan di atas adalah 0,0028 0,0031 atau $0,00 \%$ yang menunjukkan bahwa di Danau Towuti terdapat ikan gabus jenis Channa striata. Lambert et al. (2005) menyatakan bahwa suatu spesimen ditetapkan sebagai spesies baru apabila terdapat gap/situs polimorfik/keragaman sekuen gen COI lebih besar atau sama dengan $2,7 \%(\geq 2,7 \%)$.

Sekuen nukleotida gen COI ikan gabus F1 hasil domestikasi dari induk alam asal Bantaeng memiliki homologi 65\% dengan sekuen nukleotida Channa pleurophthalma asal Banjarmasin Kalimantan Selatan dan Channa gachua asal (India). Analisis filogeni menunjukkan bahwa ikan gabus asal Bantaeng, Channa pleurophthalma, dan Channa gachua masing-masing membentuk kelompok tersendiri. BLASTn sekuen nu- kleotida gen COI ikan gabus F1 asal Bantaeng dengan sekuen nukleotida Channa pleurophthalma dan Channa gachua yang terdeposit di Bank Gen menunjukkan adanya gap berturut-turut sebesar 2\% dan 3\%. Oleh sebab itu, diperlukan marka untuk menentukan jenis/spesies ikan gabus F1 asal Bantaeng tersebut.

\section{Simpulan}

Penelitian ini menyimpulkan bahwa ikan gabus jenis Channa striata terdapat di Danau Towuti Sulawesi Selatan. Nukleotida gen COI ikan gabus generasi I yang berasal dari induk yang tertangkap di perairan tawar Kabupaten Bantaeng memiliki homologi 65\% dengan nukleotida gen COI Channa pleurophthalma dari Banjarmasin Kalimantan Selatan dan Channa gachua dari India dengan gap berturut-turut 2\% dan $3 \%$.

\section{Persantunan}

Penelitian ini dibiayai oleh Direktorat Jenderal Penguatan Riset dan Pengembangan, Kementerian Riset dan Pendidikan Tinggi dengan nomor kontrak 019/SP2H/LT/DRPM/II/2016. Ucapan terima kasih disampaikan kepada LP2M Universitas Hasanuddin selaku institusi penanggungjawab kegiatan dan kepada semua pihak yang membantu dalam pengadaan sampel ikan gabus.

\section{Daftar pustaka}

Arma NR, Illijas MA, Irmawati, Mappanyiwi A. 2014. Morphometric and meristic characteristics of snakehead fish for hatchery production. In: Hutauruk et al. (ed.). Proceeding of the $3^{\text {rd }}$ International and National Seminar on Fisheries and Marine Science: Strengthening science and technology towards the development of Blue Economy, Faculty of Fisheries and Marine Science University of Riau, Riau. pp.198-201. 
Dahruddin H, Hutama A, Busson F, Sauri S, Hanner R, Keith P, Hadiaty R, Hubert N. 2017. Revisiting the ichthyodiversity of Java and Bali through DNA barcodes: taxonomic coverage, identification accuracy, cryptic diversity and identification of exotic species. Molecular Ecology Resources, 17(2): 288299.

Froese R, Pauly D. 2016. FishBase. World Wide Web electronic publication. www.fishbase. org version (10/2016).

Hebert PDN, Cywinska A, Ball SL, de Waard JR. 2003a. Biological identifications through DNA barcodes. In: Barrett S (ed.). Proceedings of The Royal Society B. Royal Society of London, 270(1512): 313-321.

Hebert PDN, Ratnasingham S, de Waard JR. 2003b. Barcoding animal life: cytochrome c oxidase subunit 1 divergences amongst closely related species. In: Barrett S (ed.). Proceedings of The Royal Society B. Royal Society of London, 270: S96-S99.

Hebert PDN, Stoeckle MY, Zemlak TS, Francis CM. 2004. Identification birds through DNA barcodes. PloS Biology, 2(10): 16571663.

Herborg LM, Mandrak NE, Cudmore BC, Maclsaac HJ. 2007. Comparative distribution and invasion risk of snakehead (Channidae) and Asian carp (Cyprinidae) species in North America. Canadian Journal of Fish Aquatic Science, 64(12): 1723-1735.

Irmawati, Nadiarti, Tresnati J, Hidayani AA, Arma NR. 2015. Reproductive performance of snakehead fish in tank. Disampaikan pada The $5^{\text {th }}$ International Conference of Aquaculture Indonesia (ICAI): "Sustainable Aquaculture for the Future", Jakarta 29 - 31 Oktober 2015 .

Lambert DM, Baker A, Huynen L, Haddrath O, Hebert PDN, Millar CD. 2005. Is a largescale DNA-based inventory of ancient life possible? Journal of Heredity, 96(3): 27984.

Lakra WS, Goswami M, Gopalakrishnan A, Singh DP, Singh A, Nagpure NS. 2010. Genetic relatedness among fish species of genus Channa using mitochondrial DNA genes. Biochemical Systematics and Ecology, 38(6): 1212-1219.

Lynch M, Jarrell PE. 1993. A method for calibrating molecular clocks and its application to animal mitochondrial DNA. Genetics, 135(4): 1197-1208.

Ma H, Ma C, Ma L. 2012. Molecular identification of genus Scylla (Decapoda: Portunidae) based on DNA barcoding and polymerase chain reaction. Biochemical Systematics and Ecology, 41: 41-47.

Mat Jais AM, Dambisya YM, Lee TL. 1997. Antinociceptive activity of Channa striatus (haruan) extracts in mice. Journal of Ethnopharmacology, 57(2): 125-130.

Michelle NYT, Shanti G, Loqman MY. 2004. Effect of orally administered Channa striatus extract against experimentally-induced osteoarthritis in rabbits. International Journal of Applied Research in Veterinary Medicine, 2(3):171-175.

Muchlisin ZA, Thomy Z, Fadli N, Sarong MA, Siti-azizah MN. 2013. DNA barcoding of freshwater fishes from Lake Laut Tawar, Aceh Province, Indonesia. Acta Ichthyologica et Piscatoria, 43(1): 21-29.

Mustafa, Widodo AMA, Kristianto Y. 2012. Albumin and zinc content of snakehead fish (Channa striatus) extract and is role and health. International Journal of Sciene and Technology, 1(2): 1-8.

Serrao NR, Steinke D, Hanner RH. 2014. Calibrating snakehead diversity with DNA Barcodes: expanding taxonomic coverage to enable identification of potential and established invasive species. Plos One, 9(6): 113.

Song LM, Munian K, Rashid AZ, Bhassu S. 2013. Characterisation of Asian snakehead Murrel Channa striata (Channidae) in Malaysia: An insight into molecular data and morphological approach. The scientific World Journal, 2013:1-16.

Tamura K, Stecher G, Peterson D, Filipski A, Kumar S. 2013. MEGA 6: Molecular evolutionary genetics analysis version 6.0. Molecular Biology and Evolution, 30(12): 27252729.

Zhu SR, Ma KY, Xing ZJ, Xie N, Wang YX, Wang Q, Li JL. 2013. The complete mitochondrial genome of Channa argus, Channa maculata and hybrid snakehead fish [Channa maculata (ㅇ) x Channa argus (수)]. Mitocondrial DNA, 24(3): 217-218. 